\title{
Influence of upward and horizontal growth direction on microstructure and microhardness of an unsteady-state directionally solidified Al-Cu-Si alloy
}

\author{
Raimundo Lucivaldo Marães de Araújo ${ }^{1}$, Rafael Hideo Lopes Kikuchi², \\ André Santos Barros ${ }^{1}$, Laércio Gouvea Gomes ${ }^{2}$ Daniel Joaquim da Conceição Moutinho², \\ Fernando de Almeida Gonçalves ${ }^{2}$, Antonio Luciano Seabra Moreira ${ }^{1}$, \\ Otávio Fernandes Lima da Rocha ${ }^{1,2}$
}

\footnotetext{
${ }^{1}$ Institute of Technology, Federal University of Pará - ITEC/UFPA - 66075-110, Belém, PA e-mail: ralma@ufpa.br; andre.barros@ufpa.br

${ }^{2}$ Federal Institute of Education, Science and Technology of Pará - IFPA - 66093-020, Belém, PA e-mail: rafael.kikuchi1991@gmail.com, laercio.gomes@ifpa.edu.br,daniel.moutinho@ifpa.edu.br, fernando.goncalves@ifpa.edu.br, otavio.rocha@ifpa.edu.br
}

\begin{abstract}
In order to analyze the effect of the growth direction on dendrite arm spacing $\left(\lambda_{1}\right)$ and microhardness (HV) during horizontal directional solidification (HDS), experiments were carried out with the Al-3wt.\%Cu$5.5 \mathrm{wt} . \% \mathrm{Si}$ alloy and the results compared with others from the literature elaborated for upward directional solidification (UDS). For this purpose, a water-cooled directional solidification experimental device was developed, and the alloy investigated was solidified under unsteady-state heat flow conditions. Thermal parameters such as growth rate $\left(\mathrm{V}_{\mathrm{L}}\right)$ and cooling rate $\left(\mathrm{T}_{\mathrm{R}}\right)$ were determined experimentally and correlations among $\mathrm{V}_{\mathrm{L}}, \mathrm{T}_{\mathrm{R}}, \lambda_{1}$ and $\mathrm{HV}$ has been performed. It is observed that experimental power laws characterize $\lambda_{1}$ with a function of $\mathrm{V}_{\mathrm{L}}$ and $\mathrm{T}_{\mathrm{R}}$ given by: $\lambda_{1}=\operatorname{constant}\left(\mathrm{V}_{\mathrm{L}}\right)^{-1.1}$ and $\lambda_{1}=\operatorname{constant}\left(\mathrm{T}_{\mathrm{R}}\right)^{-0.55}$. The horizontal solidification direction has not affected the power growth law of $\lambda_{1}$ found for the upward solidification. However, higher values of $\lambda_{1}$ have been observed when the solidification is developed in the horizontal direction. The interrelation of $\mathrm{HV}$ as function of $\mathrm{V}_{\mathrm{L}}, \mathrm{T}_{\mathrm{R}}$ and $\lambda_{1}$ has been represented by power and Hall-Petch laws. A comparison with the Al-3wt.\% Cu alloy from literature was also performed and the results show the Si element affecting significativaly the HV values.
\end{abstract}

Keywords: Horizontal directional solidification, Microstructure, Microhardnees, Al-based multicomponent alloys.

\section{INTRODUCTION}

Aluminum alloys castings have a fundamental role in the metal-mechanics industry. Nowadays these alloys are supplied in a wide range of chemical compositions [1-12]. We highlight the Al-Cu-Si ternary system because of particular outstanding properties such as high mechanical strength, low weight and very good fluidity [3-12]. These qualities make them a good choice for applications in the automotive and aerospace industry. These alloys have attracted much attention of researchers with view to investigating the microstructural evolution, formation of macrosegregation and porosity during the solidification process.

The morphology of as-cast microstructures, characterized mainly by cellular and dendritic patterns, and their scales represented by primary, secondary and tertiary arm spacings $\left(\lambda_{1}, \lambda_{2}\right.$ and $\lambda_{3}$, respectively) control the segregation profiles and the formation of secondary phases within intercellular and interdendritic regions, which determine the final properties of castings [1,2]. This is known that the values of $\lambda_{1}, \lambda_{2}$ and $\lambda_{3}$ are strongly influenced by solidification thermal parameters such as growth rate $\left(\mathrm{V}_{\mathrm{L}}\right)$ and cooling rate $\left(\mathrm{T}_{\mathrm{R}}\right)$ [1,2,3,7-12]. Several directional solidification studies have been reported in the literature to characterize and quantify these parameters as a function of solute concentration $C_{0}, V_{L}$ and $T_{R}$. 
Several investigations on directional solidification existing in the literature focusing in the interconnection among solidification thermal variables, microstructure features and mechanical properties are based on samples which were grown by a Bridgman technique. Recently, ÇADIRLI [22] has been investigated the influence of cooling rate and composition on the microhardness (HV) and ultimate tensile strength $(\sigma)$ of unidirectional solidified Al-Cu alloys during upward steady-state solidification. It has been observed that increasing copper content and cooling rate, microhardness and tensile strength increase, while strain decreases. This author have found relationships given by $\mathrm{HV}=\mathrm{k} \lambda_{1}{ }^{-\mathrm{a}}(\mathrm{a}=0.23$ to 0.29$)$.

Studies considering unsteady-state solidification deserve special attention since it is the class of heat flow encompassing the majority of industrial solidification processes. However, the vast majority of these works were developed to investigate the microstructural evolution of binary alloys in vertical upward directional solidification [1-6, 8,10-12].

In this sense, considering that studies of unsteady-state directional solidification of aluminum-based multicomponent alloys are still scarce in the literature, the main purpose of this paper is to investigate the influence of upward and horizontal growth direction on microstructure and microhardness of an unsteadystate directionally solidified Al-Cu-Si alloy

\section{EXPERIMENTAL PROCEDURE}

Experiments was performed with the Al-3wt.\%Cu-5.5wt.\%Si. The chemical compositions of metals that were used to prepare this alloy are presented in Table 1. Starting melt superheat was standardized at 1.1 times the liquidus temperature $\left(\mathrm{T}_{\mathrm{L}}\right)$ of the alloy analyzed.

Table 1: Chemical composition of the metals used to prepare the Al-Cu-Si alloy investigated.

\begin{tabular}{cccccccccccc}
\hline METAL & $\mathbf{A l}$ & $\mathbf{F e}$ & $\mathbf{N i}$ & $\mathbf{S i}$ & $\mathbf{P}$ & $\mathbf{C a}$ & $\mathbf{T i}$ & $\mathbf{Z n}$ & $\mathbf{G a}$ & $\mathbf{C u}$ & $\mathbf{V}$ \\
\hline $\mathrm{Al}$ & 99.7 & 0.176 & 0.006 & 0.062 & - & - & 0.009 & 0.007 & 0.012 & - & 0.011 \\
$\mathrm{Si}$ & 0.1094 & 0.3164 & 0.0102 & 99.596 & 0.010 & 0.0214 & 0.0455 & - & - & - & - \\
$\mathrm{Cu}$ & 0.0951 & - & - & - & 0.045 & - & - & - & - & 99.859 & - \\
\hline
\end{tabular}

The casting assembly used in solidification experiments is schematized in Figure 1. The directional solidification device was designed to permit heat extraction only through the water-cooled system placed in the lateral mold wall, promoting horizontal directional solidification. The main design criterion was to induce unidirectional heat flow during solidification. A stainless steel mold used had a wall thickness of $3 \mathrm{~mm}$, a length of $160 \mathrm{~mm}$, a height of $60 \mathrm{~mm}$ and a width of $60 \mathrm{~mm}$. During the solidification process, temperatures at different positions in the alloy samples were measured and the data were acquired automatically. For the measurements, a set of six fine type $\mathrm{K}$ thermocouples, arranged as shown in Figure 1, was used. The thermocouples were sheathed in 1.6mmdiameter steel tubes, and positioned at 5, 15, 30, 50, 70 and $90 \mathrm{~mm}$ from the heat-extracting surface.

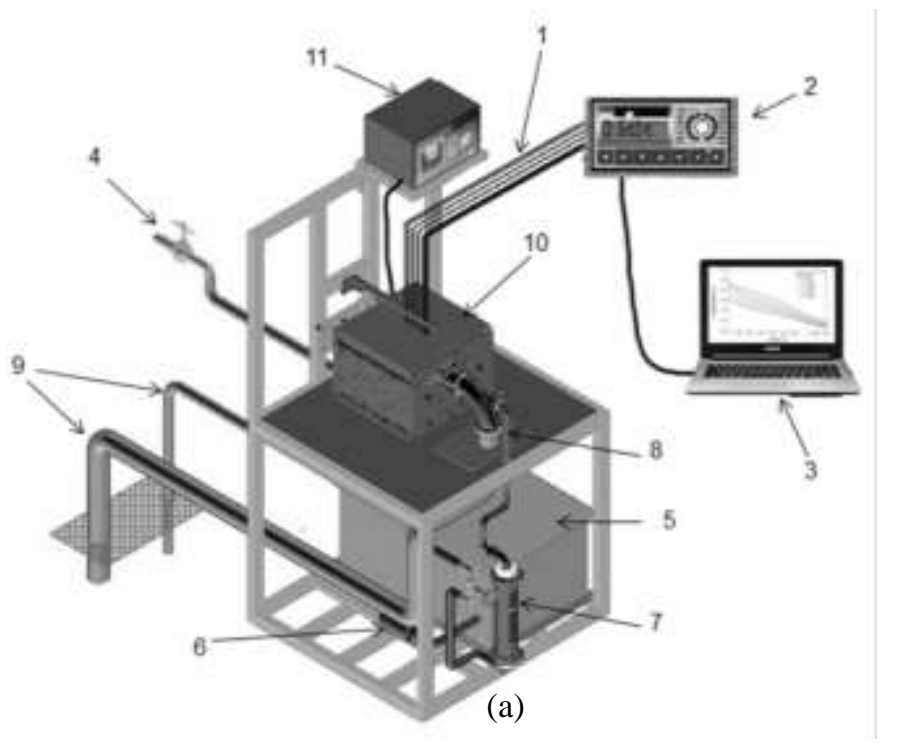

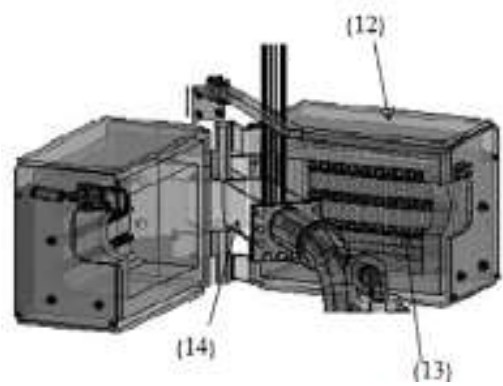

(b) 
Figure 1: (a) Schematic representation of the horizontal experimental solidification setup: (1) thermocouples, (2) field logger, (3) computer and data acquisition software, (4) feed water, (5) water container, (6) water pump, (7) rotameter, (8) water inlet, (9) water outlet, (10) directional solidification device and (11) temperature controller; (b) view inside of the solidification device: (12) insulating ceramic shielding, (13) electric heaters and (14) rectangular mold (stainless steel mold - inner wall).

The casting was longitudinally sectioned from the center and the macrostructure was examined, According to scheme shown in Figure 2a. The solution composed of $5 \mathrm{~mL} \mathrm{of} \mathrm{H}_{2} \mathrm{O}, 60 \mathrm{~mL}$ of $\mathrm{HCl}, 30 \mathrm{~mL}$ of $\mathrm{HNO}_{3}$ and $5 \mathrm{~mL}$ of $\mathrm{HF}$ was used to reveal the macrostructure. Selected transverse sections (perpendicular to the growth direction) of the directionally solidified specimens at 2, 4, 6, 8, 10, 15, 20, and $30 \mathrm{~mm}$ from the metal-mold interface were polished and etched with a solution of $5 \%$ of $\mathrm{NaOH}$ in water for micrograph examination. Figure $2 b$ represents the macrostructure revealed to alloy analyzed in this study and removed positions of the ingot to microstructural analysis. Image processing system Olympus BX51 and Image Tool (IT) software were used to measure primary arm spacing (about 20 independent readings for each selected position, with the average taken to be the local spacing) and their distribution range. The method used for measuring the primary arm spacing on the transverse section was the triangle method [10]. Measurement of the primary dendritite arm spacings on the transverse section was carried out using the triangle method $[25,28]$. The triangle is formed by joining the three neighboring dendrite centers, the sides of the triangle corresponding to $\lambda_{1}$, as shown in Figure 3. Microstructures of directionally solidified samples were also characterized using a scanning electron microscope (SEM Shimadzu, VEGA 3 SBU TESCAM) coupled to an energy dispersion spectrum (EDS AZTec Energy X-Act, Oxford).

The mechanical properties of any solidified material are usually determined using hardness, tensile, and ductility tests [13]. The microhardness measurements in this work were performed using a Shimadzu HMV-2 model hardness measuring test device using a $50 \mathrm{~g}$ load and a dwell time of $10 \mathrm{~s}$. The adopted Vickers microhardness values were the average of at least 20 different measurements on the transverse section of each sample. The experimental results of each microhardness value as a function of both the position and primary dendritic arm spacing are represented by a variation between the minimum and maximum limit obtained from 20 different measurements.

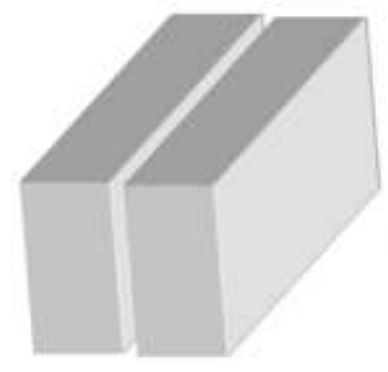

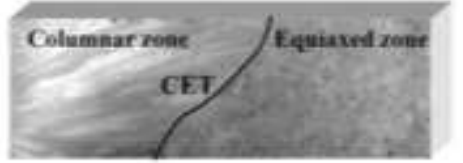

(a)

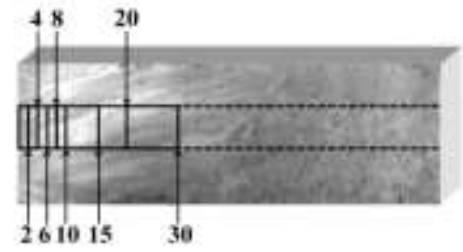

(b)

Figure 2: Schematic representation of removal of ingot samples for macrostructural and microstructural analysis: (a) longitudinal cut of the ingot and revelation of solidification macrostructure and (b) cutting positions of the samples for measurement of primary spacings.
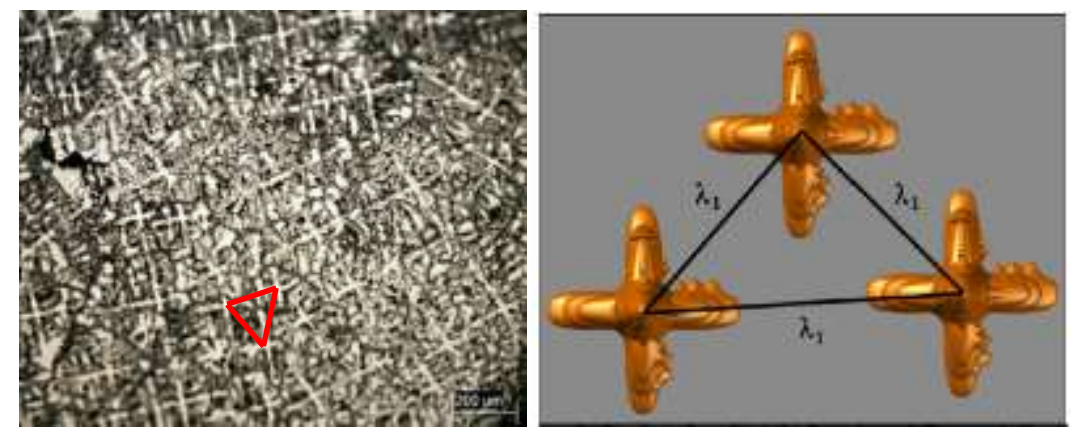
Figure 3: Triangle method for measurement of $\lambda_{1}$ values: (a) dendritic microstructure obtained in this work, showing the distances between primary arms centers forming a triangle and (b) schematic representation of the method.

\section{RESULTS AND DISCUSSION}

Experimental cooling curves for six thermocouples inserted into the casting during solidification of the alloy investigated in this study are shown in Figure 4.
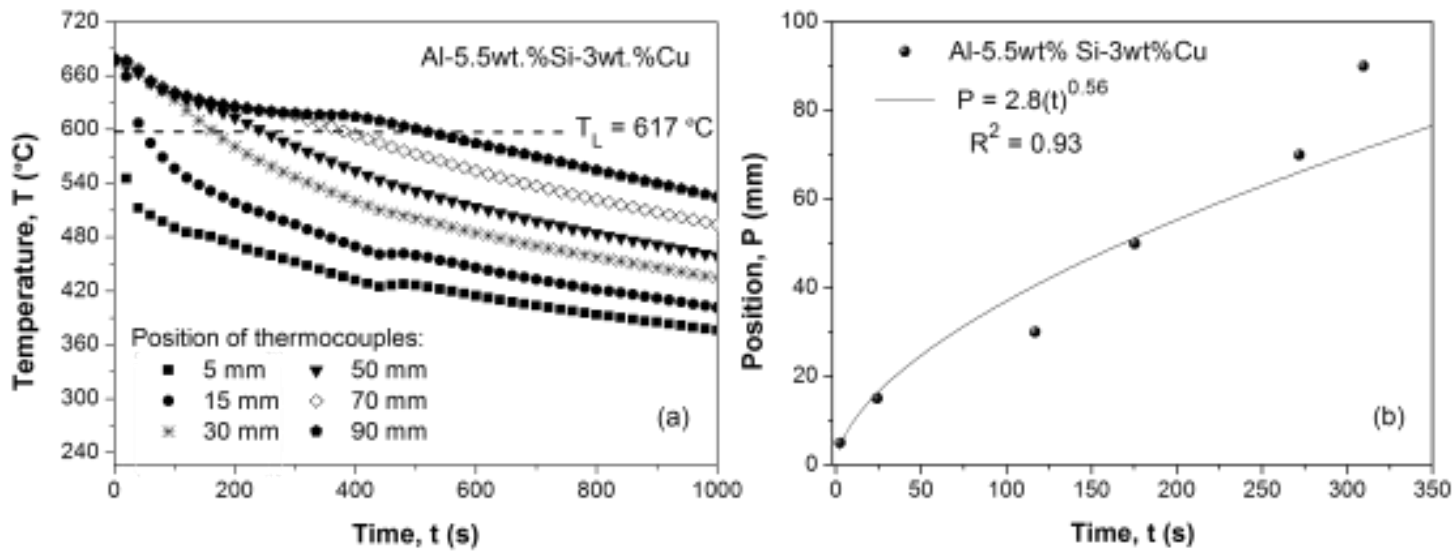

Figure 4: (b) Temperature profiles obtained for $\mathrm{Al}-\mathrm{Cu}-\mathrm{Si}$ alloy analyzed in this work with $10 \%$ of superheat and (b) liquidus isotherm experimental position of from the metal-mold interface as function of time.

The primary dendritic arm spacings are dependent on solidification thermal parameters such as $\mathrm{V}_{\mathrm{L}}$ and $T_{R}$. In order to determine more accurate values of these parameters, the results of experimental thermal analysis, shown in Figure 4 a have been used to generate a plot of position from the metal/ mold interface as a function of time corresponding to the liquidus front passing by each thermocouple. This methodology has been detailed in our recently published articles [7-14]. A curve fitting technique on such experimental points has generated a power function of position as a function of time (see Figure $4 \mathrm{~b}$ ). The derivative of this function with respect to time has yielded values for $V_{L}$, shown in Figure 5a. Figure $5 b$ shows the $T_{R}$ profile, which was calculated by considering the thermal data recorded immediately after the passing of the liquidus front by each thermocouple [7-14].
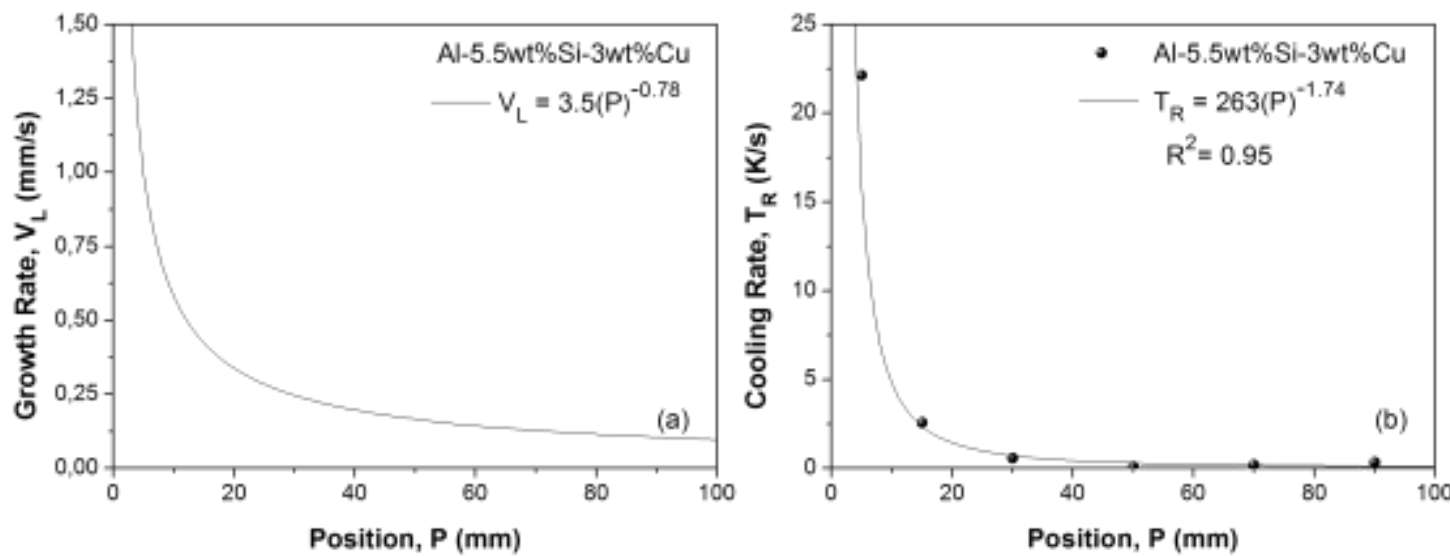

Figure 5: Experimental results of thermal parameters analyzed in this study: (a) growth rate as a function of position from the metal/mold interface and (b) cooling rate as a function of position from the metal/mold interface.

It can be seen in Figures $5 \mathrm{a}$ and $5 \mathrm{~b}$ that the use of a water cooled mold imposes higher values of $\mathrm{V}_{\mathrm{L}}$ and $\mathrm{T}_{\mathrm{R}}$ near the metal/mold interface and a decreasing profile along the casting due to the increasing thermal 
resistance of the solidified layer with distance from the heat-extracting surface. This influence of the solidification thermal variables translates to the observed experimental values of $\lambda_{1}$ as shown in Figure 6, where average values with the standard variation of are plotted as a function of $V_{\mathbf{L}}$ and $T_{\mathbf{R}}$. It is observed in Figures $6 \mathrm{a}$ and $6 \mathrm{~b}$ that power laws equal to -1.1 and -0.55 characterize the experimental variation of primary spacing with growth rate and cooling rate, respectively, i.e, $\lambda_{1}=96\left(\mathrm{~V}_{\mathrm{L}}\right)^{-1.1}$ and $\lambda_{1}=396\left(\mathrm{~T}_{\mathrm{R}}\right)^{-0.55}$. This is in agreement with observations reported by ROCHA et al. [10], PERES et al. [5], CARVALHO et al. [7], CRUZ et al. [15] BARROS et al. [13] COSTA et al. [12] and GOMES [16] that exponential relationships and $\lambda_{1}=$ constant $\left(\mathrm{V}_{\mathrm{L}}\right)^{-1.1}$ and $\lambda_{1}=\mathrm{constant}\left(\mathrm{T}_{\mathrm{R}}\right)^{-0.55}$ best generate the experimental variation of primary dendritic arms with $\mathrm{V}_{\mathrm{L}}$ and $\mathrm{T}_{\mathrm{R}}$ along the unsteady-state solidification of Al-Cu, Al-Si, Al-Sn, Al-Cu, Al-Cu-Si and $\mathrm{Al}-\mathrm{Cu}-\mathrm{Si}$ alloys, respectively. With a view to analyzing the effect of Si element in binary Al-3wt.\% Cu alloy as well as the influence of growth direction on the length scale of the dendritic microstructure $\left(\lambda_{1}\right)$ the average, maximum and minimum values of the correlation between $\lambda_{1}$ and $T_{R}$ of this work are plotted in Figure 7 and compared with the experimental equations obtained by BARROS et al. [13] and GOMES [16], whose works have been developed to horizontal and upward directional solidification, respectively. When comparing the mean values of $\lambda_{1}$ obtained in the present study with those reported recently by BARROS et al. [13] (see Figure 7) similar growth laws can be observed, i.e., the addition of Si in the Al-3wt.\%Cu alloy seems to have no noticeable effects on reduction in the length scale of the $\lambda_{1}$ values during horizontal directional solidification. On the other hand, considering the experimental law $\lambda_{1}=f\left(T_{R}\right)$ in both growth configurations (upward and horizontal), the experimental spectrum of $\lambda_{1}$ values of the Al-3wt.\%Cu$5.5 \mathrm{wt} . \% \mathrm{Si}$ alloy is higher for the horizontally solidified casting than that verified by GOMES [16] during upward directional solidification. It is usually assumed that the effect of the natural convection in the liquid can be neglected during upward vertical solidification [5, 17]. In contrast, for horizontal directional configuration the solute-enriched liquid located in the interdendritic regions and ahead the dendrite tips, induced thermosolutal convection since it is denser than the bulk liquid [12]. COSTA et al. [12] reported that the absence of melt convection during upward solidification of $\mathrm{Al}-\mathrm{Cu}-\mathrm{Si}$ alloys forces the rejected $\mathrm{Si}$ to be confined in the interdendritic regions, thus raising the constitutional supercooling, leading to the onset of tertiary. These tertiary branches have a growth character similar to that of the primary branches and their presence will provide new primary arms [18] grown from the secondary branches. This, as a consequence, will reduce the interdendritic spacing between primary arms, as can be observed in the present investigation.
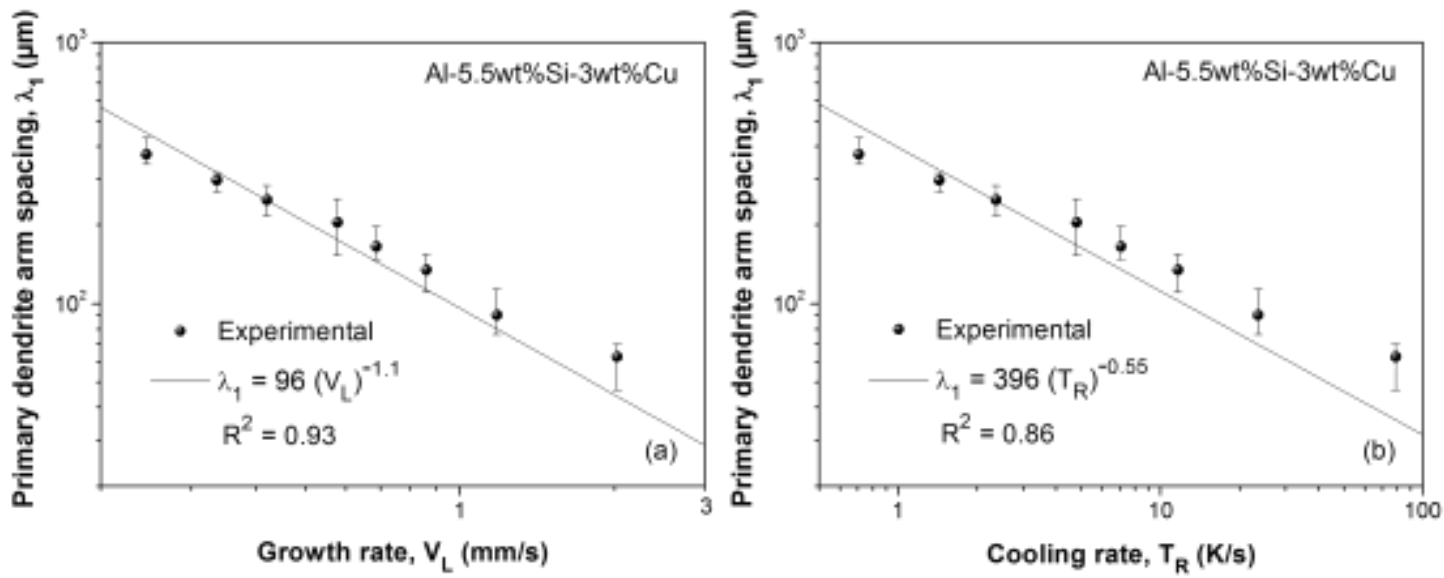

Figure 6: (a) Primary dendrite arm spacing as a function of growth rate and (b) primary dendrite arm spacing as a function of cooling rate. 


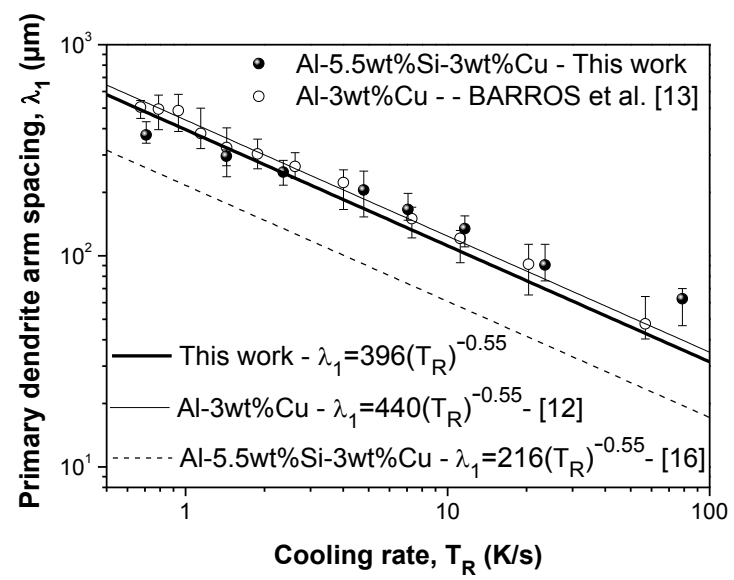

Figure 7: Primary dendrite arms spacing as a function of cooling rate: Comparison among the results obtained in this work with those obtained by BARROS et al. [13] and GOMES [16].

Typical solidification microstructures of transverse section of the samples at 10 and $30 \mathrm{~mm}$ from metal/mold interface, showing the primary dendrite arms are shown in Figure 8 . It can be characterized by $\alpha-\mathrm{Al}$ phase of dendritic morphology, with Si particles in the aluminum-rich matrix as well distributed along the interdendritic regions in the eutectic mixture interlinked with $\mathrm{Al}_{2} \mathrm{Cu}$ intermetallic phase developing the microstructure $\alpha-\mathrm{Al}+\mathrm{Al}_{2} \mathrm{Cu}+\mathrm{Si}$. Figure 9 depicts some detailed images by SEM-EDS mapping. It can be observed that the points $1,2,3,4$ and 5 indicate the place where microanalysis by SEM-EDS mapping have been carried out, and the arrows represent the microstructural phases present in the analyzed alloy. This is confirmed the presence of $\mathrm{Si}$ particles in the interdendritic regions very close to the $\mathrm{Al}_{2} \mathrm{Cu}$ intermetallic phases, as shown in the microanalysis of points 4 and 5 .
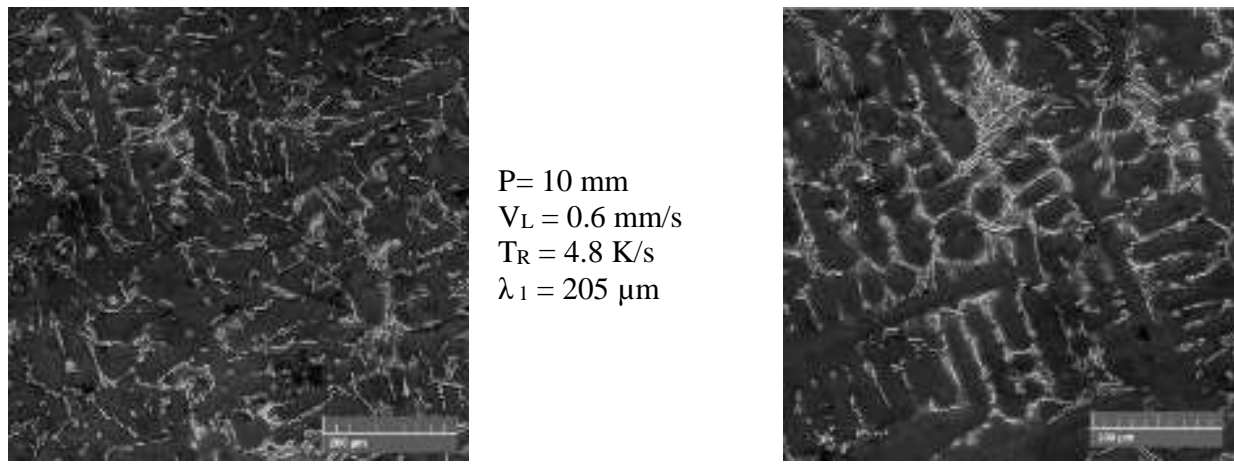

$\mathrm{P}=30 \mathrm{~mm}$

$\mathrm{V}_{\mathrm{L}}=0.24 \mathrm{~mm} / \mathrm{s}$

$\mathrm{V}_{\mathrm{L}}=0.6 \mathrm{~mm} / \mathrm{s}$

$\mathrm{T}_{\mathrm{R}}=4.8 \mathrm{~K} / \mathrm{s}$

$\lambda_{1}=205 \mu \mathrm{m}$
$\mathrm{T}_{\mathrm{R}}=0.71 \mathrm{~K} / \mathrm{s}$

$\lambda_{1}=373 \mu \mathrm{m}$

Figure 8: Solidification microstructures of obtained for the Al-Cu-Si alloy analyzed in this work. 


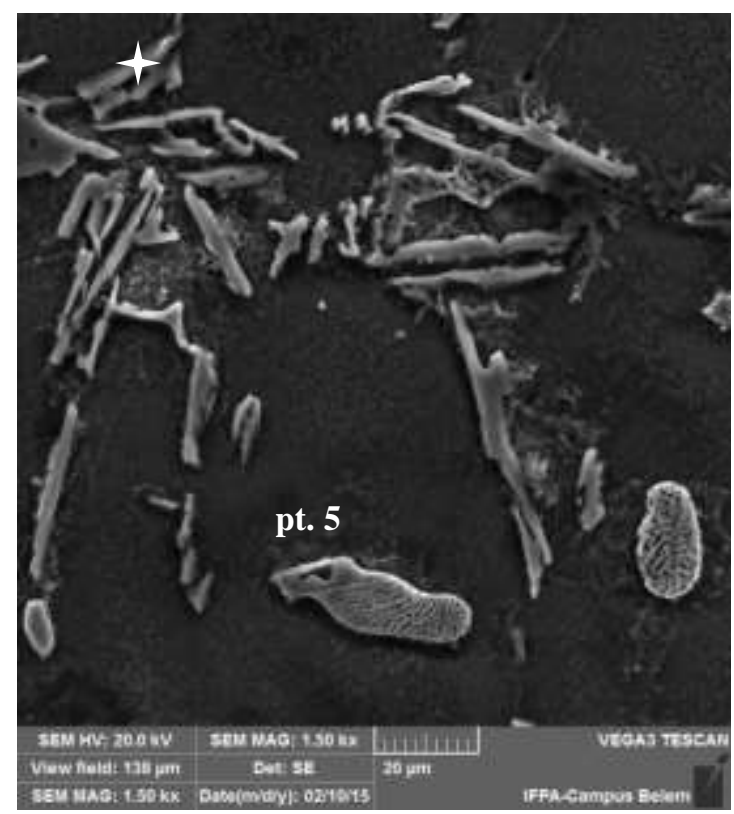

\begin{tabular}{ccccc}
\hline \multirow{2}{*}{ Point } & \multicolumn{4}{c}{ Weigth (\%) } \\
\cline { 2 - 5 } & $\mathbf{A l}$ & $\mathbf{C u}$ & $\mathbf{S i}$ & $\mathbf{F e}$ \\
\hline 1 & 97.5 & 1.28 & 1.22 & - \\
\hline 2 & 31.34 & 57.18 & 11.48 & - \\
\hline 3 & 26.6 & 61.55 & 8.05 & 3.8 \\
\hline 4 & 30.93 & 1.4 & 67.67 & - \\
\hline 5 & 7.47 & 0.98 & 91.56 & - \\
\hline
\end{tabular}

(b)

(a)

Figure 9: (a) Typical SEM micrograph at position of $10 \mathrm{~mm}$ from metal/mold interface and (b) EDS patterns and the corresponding chemical composition.

Expressions correlating the mechanical behavior with features of the as-solidified microstructure can enable metal production industries to optimize the cast alloy properties. KAYA et al. [21] reports that microhardness analysis seems to be one of the easiest and most straightforward techniques of monitoring mechanical properties. Figure 10 shows the dependence of the microhardness $(\mathrm{HV})$ on the distance $(\mathrm{P})$ from the metal-mold interface (Figure 10a) and $\lambda_{1}$ (Figures 10b and 10c) for the alloy investigated. It is observed that the Figures $10 \mathrm{~b}$ and $10 \mathrm{c}$ depicts the evolution of $\mathrm{HV}$ with the measured primary dendrite arm spacings along the casting length. The microhardness is higher for smaller dendritic spacings (at regions close to the cooled surface of the casting). This can be noted that the microhardness results decrease with an increase in the $\lambda_{1}$ values, and the dependence of HV on $\lambda_{1}$ and $\lambda_{1}{ }^{-1 / 2}$ can also be represented by power and Hall-Petch type equations given by $\mathrm{HV}=215\left(\lambda_{1}\right)^{-0.16}$ and $\mathrm{HV}=64+401\left(\lambda_{1}\right)^{-1 / 2}$, respectively. Figure 10 compares also the powertype experimental law obtained for the ternary $\mathrm{Al}-3 \mathrm{wt} . \% \mathrm{Cu}-5.5 \mathrm{wt} . \% \mathrm{Si}$ alloy of the present study with the experimental laws proposed by BARROS et al. [13] for the binary Al-3wt.\% Cu alloy solidified under the same conditions of this study. It can be seen that the addition of Si in binary Al-Cu alloy increases $\mathrm{HV}$ values in the ternary Al-Cu-Si alloy. Figure This is verified in Fugure 9 the presence of primary silicon isolated particles dispersed in eutectic-matrix, which appear to be responsible for the high hardness noted in Al3 wt. $\% \mathrm{Cu}-5.5$ wt. $\%$ Si of this work. 

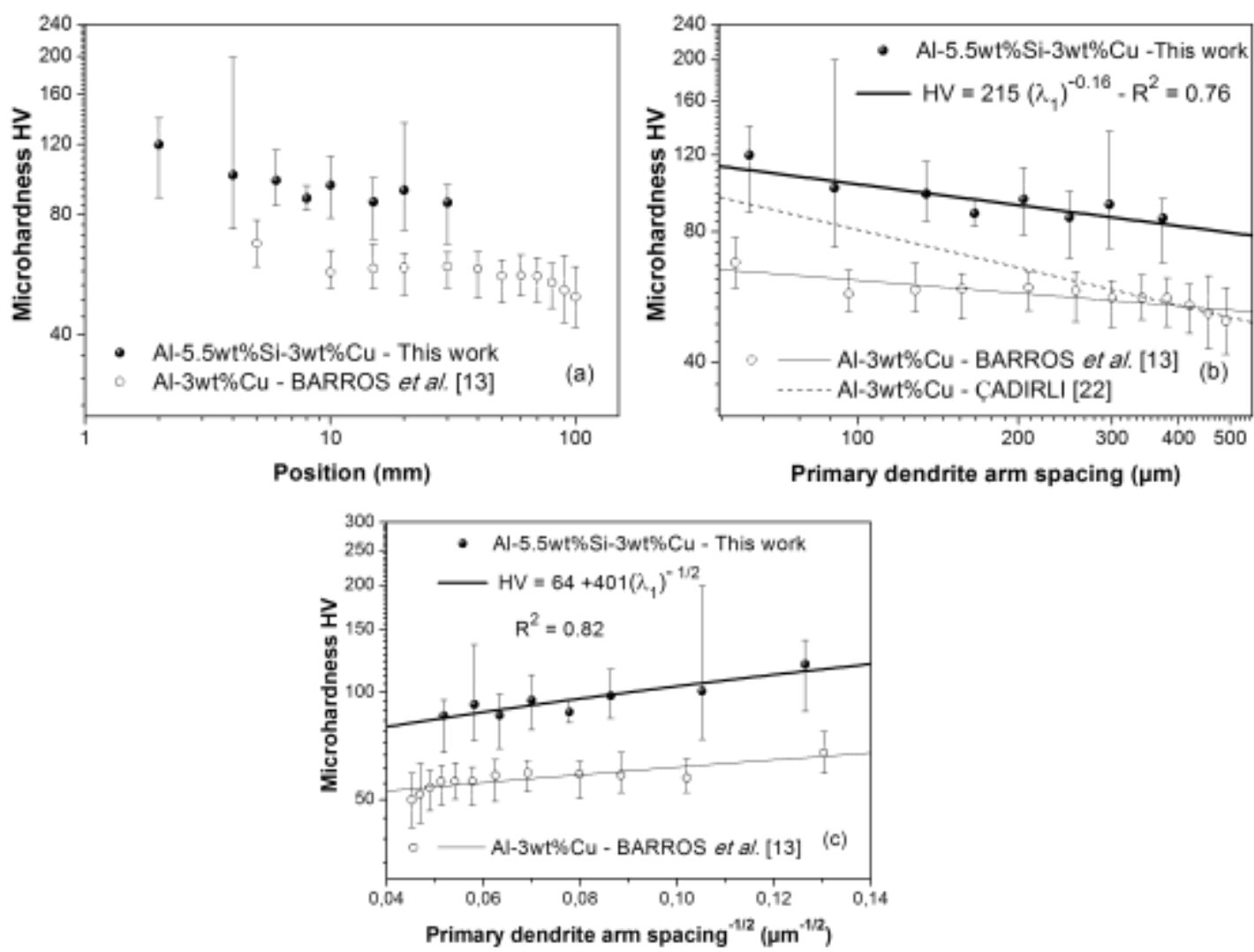

Figure 10: Microhardness evolution for the analyzed alloy as a function of (a) liquidus isotherm position (P), (b) $\lambda_{1}$, and (c) $\lambda_{1}^{-1 / 2}$.

According to ÇADIRLI [22], characteristics of cooling rate play a vital role for a good combination of microstructure and mechanical properties. Furthermore, Figure 11 depicts the evolution of HV with the thermal parameters $\mathrm{V}_{\mathrm{L}}$ and $\mathrm{T}_{\mathrm{R}}$ (Figures $11 \mathrm{a}$ and $11 \mathrm{~b}$ ) for the alloy investigated. HV increases to higher values of $\mathrm{V}_{\mathrm{L}}$ and $\mathrm{T}_{\mathrm{R}}$. The association of $\mathrm{HV}$ with $\mathrm{V}_{\mathrm{L}}$ and $\mathrm{T}_{\mathrm{R}}$ can be represented also by power type laws given by $\mathrm{HV}=101\left(\mathrm{~V}_{\mathrm{L}}\right)^{0.14}$ and $\mathrm{HV}=85\left(\mathrm{~T}_{\mathrm{R}}\right)^{0.06}$. It should be emphasized that smaller primary dendritic spacing were obtained for higher growth rate and cooling rate, as can be seen in Figures 6 and 7, thus affecting the HV values. In Figure 11 the experimental law proposed by ÇADIRLI [22] and results obtained by KARAKÖSE and KESKIN [20] are presented, in these works the cooling rates applied were between 0.01 and $4 \mathrm{~K} / \mathrm{s}$ and $1.7 \times 10^{6}$ to $3.7 \times 10^{7} \mathrm{~K} / \mathrm{s}$, respectively. It is observed for low $\mathrm{T}_{\mathrm{R}}$ values a reasonable approximation of the laws obtained in this work and Çadirli. On the other hand, it is observed that the values obtained by Karokose and Keskin and Barros et al underestimate the experimental results of this work. 

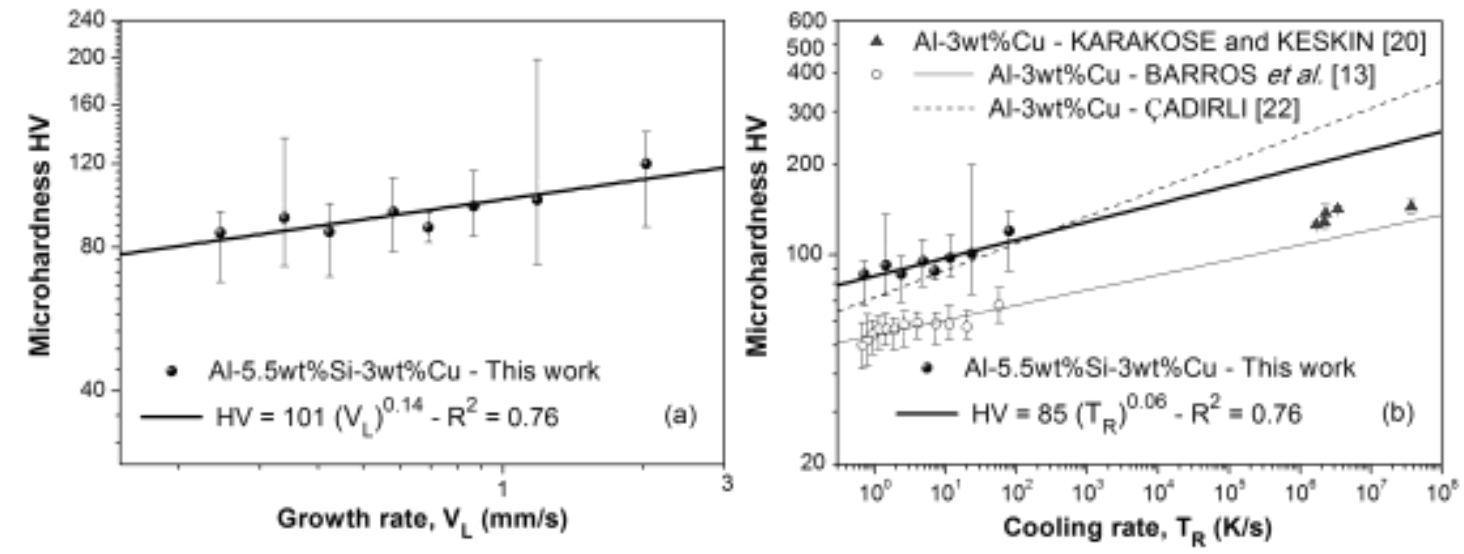

Figure 11: Microhardness evolution for the analyzed alloy as a function of (a) growth rate $\left(\mathrm{V}_{\mathrm{L}}\right)$ and $(\mathrm{b})$ cooling rate $\left(\mathrm{T}_{\mathrm{R}}\right)$.

\section{CONCLUSION}

The following major conclusions can be drawn from this study, where Al-3wt.\% Cu-5.5wt.\% Si alloy has been directionally solidified under unsteady-state heat flow conditions:

(a) Under transient horizontal solidification conditions the primary dendritic spacings were observed to decrease when tip growth rate and cooling rate are increased.

(b) Relations between $\lambda_{1}$ with the growth rate and cooling rate were obtained by the following experimental laws: $\lambda_{1}=96\left(\mathrm{~V}_{\mathrm{L}}\right)^{-1.1}$ and $\lambda_{1}=396\left(\mathrm{~T}_{\mathrm{R}}\right)^{-0.55}$.

(c) The microhardness (HV) dependency on the thermal parameters and microstructure $\left(\lambda_{1}\right)$ can be represented by power and Hall-Petch-type relationships given by $\mathrm{HV}=101\left(\mathrm{~V}_{\mathrm{L}}\right)^{0.14}, \mathrm{HV}=85\left(\mathrm{~T}_{\mathrm{R}}\right)^{0.06}, \mathrm{HV}$ $=215\left(\lambda_{1}\right)^{-0.16}$ and $\mathrm{HV}=64+401\left(\lambda_{1}\right)^{-1 / 2}$.

(d) The presence of $\mathrm{Si}$ element in the Al-Cu-Si alloy investigated in this study allowed to obtain smaller primary dendrite arm spacing in comparison with the binary A-Cu alloy (BARROS et al. [13]) as well as $\mathrm{Si}$ added in the Al-Cu alloy to form the ternary $\mathrm{Al}-\mathrm{Cu}-\mathrm{Si}$ alloy has increased the microhardness values.

(e) This study may contribute to for liquid metal processing in industry aiming at designing of a required alloy microstructure and mechanical properties, considering a better understanding of the thermal parameters and processes occurred in the $\mathrm{Al}-\mathrm{Cu}$ and $\mathrm{Al}-\mathrm{Cu}-\mathrm{Si}$ alloys.

\section{ACKNOWLEDGEMENTS}

The authors acknowledge the financial support provided by IFPA (Federal Institute of Education, Science and Technology of Pará), UFPA (Federal University of Pará), CAPES (Coordination of Superior Level Staff Improvement) and CNPq (the Brazilian Research Council), Brazil.

\section{BIBLIOGRAPHY}

[1]BOUCHARD, D., KIRKALDY, J.S., "Prediction of dendrite arm spacings in unsteady and steady state heat flow of unidirectionally solidified binary alloys", Metallurgical and Materials Transactions B, v.28, pp. 651-663, 1997.

[2] HUNT, J.D., LU S.Z., "Numerical modeling of cellular/dendritic array growth: spacing and structure predictions", Metallurgical Materials Transactions A, v.27, pp. 611-623, 1966.

[3] FERREIRA, I.L., LINS, J.F.C., MOUTINHO, D.J., et al., "Numerical and experimental investigation of microporosity formation in a ternary $\mathrm{Al} \mathrm{Cu} \mathrm{Si} \mathrm{alloy",} \mathrm{Journal} \mathrm{of} \mathrm{Alloys} \mathrm{Compounds,} \mathrm{v.} \mathrm{503,} \mathrm{pp.} \mathrm{31-39,} 2010$.

[4] RAPPAZ, M., BOETTINGER, W.J., "On dendritic solidification of multicomponent alloys with unequal liquid diffusion coefficients”, Acta Materialia, v. 47, pp. 3205-3219, 1999.

[5] PERES, M.D., SIQUEIRA, C.A., GARCIA, A., "Macrostructural and microstructural development in AlSi alloys directionally solidified under unsteady-state conditions", Journal of Alloys and Compounds, v. 381, pp. 168-181, 2004.

[6] EASTON, M., DAVIDSON, C., JOHN, D., "Effect of alloy composition on the dendrite arm spacing of multicomponent aluminum alloys", Metallurgical and Materials Transactions A, v.41, pp. 1528-1538, 2010. 
[7] CARVALHO, D.B., MOREIRA, A.L., MOUTINHO, D.J., et al., "The columnar to equiaxed transition of horizontal unsteady-state directionally solidified Al-Si alloys", Materials Research, v. 17, pp. 498-510, 2013.

[8] GOMES, L.G., ROCHA, O.L., MOUTINHO, D.J.C., et al., "The Growth of Secondary Dendritic Arms in Directionally Solidified Al-Si-Cu alloys: a comparative study with binary Al-Si alloys", Applied Mechanics and Materials, v. 719-720, pp. 102-105, 2015.

[9] SILVA, J.N., MOUTINHO, D.J., MOREIRA, A.L., et al., "The columnar to equiaxed transition during the horizontal directional solidification of Sn-Pb alloys" Journal of Alloys and Compounds, v.478, pp. 358366, 2009.

[10] ROCHA, O.L., SIQUEIRA, C.A., GARCIA, A., "Heat flow parameters affecting dendrite spacings during unsteady-state solidification of $\mathrm{Sn}-\mathrm{Pb}$ and $\mathrm{Al}-\mathrm{Cu}$ alloys", Metallurgical and Materials Transactions A, v. 34, pp. 995-1006, 2003.

[11] ROCHA, O.L., GOMES L.G., MOUTINHO, D.J.C., et al, "The columnar to equiaxed transition in the directional solidification of aluminum based multicomponent alloys", Revista Escola de Minas, v. 68, pp. 8590, 2015.

[12] COSTA T.A., MOREIRA, A.L., MOUTINHO, D.J., et al., "Growth direction and Si alloying affecting directionally solidified structures of Al-Cu-Si alloys", Materials Science and Technology. v. 31, pp.11031112, 2015.

[13] BARROS, A.S., MAGNO, I.A., SOUZA, F.A., et al., "Measurements of microhardness during transient horizontal directional solidification of Al-rich Al-Cu alloys: effect of thermal parameters, primary dendrite arm spacing and $\mathrm{Al}_{2} \mathrm{Cu}$ intermetallic phase", Metals and Materials International, v. 21, pp. 429-439, 2015.

[14] DIAS FILHO, J.M., KIKUCHI, R.H., COSTA, T.A.P.S., et al., "Influência das variáveis térmicas sobre os espaçamentos dendríticos terciários durante a solidificação direcional horizontal da liga Al-6\%Cu", Matéria, v. 20, pp.47-63, 2015.

[15] CRUZ, K.S, MEZA, E.S, FERNANDES, F.A.P, et al., "Dendritic arm spacing affecting mechanical properties and wear behavior of $\mathrm{Al}-\mathrm{Sn}$ and $\mathrm{Al}-\mathrm{Si}$ alloys directionally solidified under unsteady-state conditions", Metallurgical and Materials Transactions A, v. 41, pp. 972-984, 2010.

[16] GOMES, L.G., Microestrutura Dendrítica, Macrossegregação e Microporosidade na Solidificação de Ligas Ternárias Al-Si-Cu. PhD Thesis, UNICAMP, Campinas, SP, Brasil, 2012.

[17] MAGNUSSON, T., ARNBERG, L., "Density and solidification shrinkage of hypoeutectic aluminumsilicon alloys", Metallurgical and Materials Transactions A, v. 32, pp. 2605- 2613, 2001.

[18] CURRERI, P.A., LEE, J.E., STEFANESCU, D.M., "Dendritic solidification of alloys in low gravity", Metallurgical Transactions A, V. 19, pp. 2671-2676, 1998.

[19] PARK, M., "Effect of Si addition on the precipitation of $\mathrm{Al}_{2} \mathrm{Cu}$-phase in Al-Cu-Si thin films", Journal of Materials Science, v. 40, pp. 3945-3949, 2005

[20] KARAKÖSE, E., KESKIN, M., "Structural investigations of mechanical properties of Al based rapidly solidified alloys", Materials and Design, v. 32, 4970-4979, 2011.

[21] KAYA, H., ÇADIRLI, E., BÖYÜK, U., et al., "Variation of microindentation hardness with solidification and microstructure parameters in the Al based alloys", Applied Surface Science, v. 255, pp.3071- 3078, 2008

[22] ÇADIRLI, E., "Effect of solidification parameters on mechanical properties of directionally solidified Al-rich Al-Cu Alloys”, Metals and Materials International, v. 19, pp. 411-422, 2013. 